NBER WORKING PAPER SERIES

ARRESTING BANKING PANICS:

FED LIQUIDITY PROVISION AND THE FORGOTTEN PANIC OF 1929

\author{
Mark Carlson \\ Kris James Mitchener \\ Gary Richardson \\ Working Paper 16460 \\ http://www.nber.org/papers/w16460
}

\author{
NATIONAL BUREAU OF ECONOMIC RESEARCH \\ 1050 Massachusetts Avenue \\ Cambridge, MA 02138 \\ October 2010
}

We thank Jessica Van Dyke, Andrea Bui, and Joanna Do for invaluable research assistance. Mitchener thanks Sharon Boucher for help with accessing Atlanta Fed archival materials. We thank Chris Haines, Masazumi Hattori, Masami Imai, and David Wheelock as well as seminar participants at the University of Arizona, NYU-Stern, Stanford University, the Bank of Japan, NBER Summer Institute, and the All-UC Conference in Economic History for useful comments and suggestions. The views presented in this paper are solely those of the authors and do not necessarily represent those of the Federal Reserve System, its staff, or the National Bureau of Economic Research.

NBER working papers are circulated for discussion and comment purposes. They have not been peerreviewed or been subject to the review by the NBER Board of Directors that accompanies official NBER publications.

(C) 2010 by Mark Carlson, Kris James Mitchener, and Gary Richardson. All rights reserved. Short sections of text, not to exceed two paragraphs, may be quoted without explicit permission provided that full credit, including $\odot$ notice, is given to the source. 
Arresting Banking Panics: Fed Liquidity Provision and the Forgotten Panic of 1929

Mark Carlson, Kris James Mitchener, and Gary Richardson

NBER Working Paper No. 16460

October 2010

JEL No. E44,E58,G21,N22

\begin{abstract}
Scholars differ on whether Federal Reserve intervention mitigated banking panics during the Great Depression and in recent years. The last panic prior to the Depression sheds light on this debate. In April 1929, a fruit fly infestation in Florida forced the U.S. government to quarantine fruit shipments from the state and destroy infested groves. When Congress recessed in June without approving compensation for farmers, depositors in citrus growing regions began withdrawing deposits from banks, culminating in runs on institutions in the financial center of Tampa and surrounding cities. Using archival evidence, we describe how the Federal Reserve Bank of Atlanta halted the spread of the panic by rushing currency to member banks. Analysis based on a new micro-level database of commercial banks in Florida shows that bank failures would have been twice as high without the Fed's intervention. The policy response of the Fed ended the panic and suggests that similar interventions by the Fed may have been useful during the Great Depression, even in cases where banks faced questions about their solvency.
\end{abstract}

Mark Carlson

Federal Reserve Board

20th and Constitution Ave., NW

Washington, DC 20551

mark.a.carlson@frb.gov

Kris James Mitchener

Department of Economics

Leavey School of Business

Santa Clara University

Santa Clara, CA 95053

and NBER

kmitchener@scu.edu

\author{
Gary Richardson \\ Department of Economics \\ University of California, Irvine \\ 3155 Social Sciences Plaza \\ Irvine, CA 92697-5100 \\ and NBER \\ garyr@uci.edu
}




\section{ARRESTING BANKING PANICS: FED LIQUIDITY PROVISION AND THE FORGOTTEN PANIC OF 1929}

\section{Introduction}

The financial crisis of 2008-9 saw markets and institutions suffer from illiquidity and insolvency. These factors can interact and feed off of each other. For example, if market participants lower the valuations of the assets on financial intermediaries' balance sheets, it may call into question the solvency of these firms, prompting collateral calls and a flight by suppliers of short-term funds. An inability to obtain accurate information on the fundamental values of assets on balance sheets might also lead intermediaries to become unwilling to lend to each other. As institutions worry about their own need for capital and their ability to meet investor withdrawals, they may retrench, hoard liquid assets, and fail to provide funds to other distressed financial institutions; in extreme conditions, the need to raise cash can result in asset sales at depressed prices (a "fire sale") so that liquidity problems can accentuate solvency concerns (Brunnermeier and Pederson 2009, Diamond and Rajan 2005). In addition, worsening concerns over solvency can increase the likelihood of a liquidity crisis or a run on a financial institution (Morris and Shin 2000, Diamond and Rajan 2005). The response of a central bank or lender of last resort to banking crises often involves gauging the relative importance of illiquidity and insolvency. The larger role that illiquidity plays in the crisis, the more vigorously a lender of last resort may deem it necessary to extend credit in order to quell a panic. ${ }^{1}$ For example, during the recent financial crisis, the Federal Reserve introduced a host of lending programs to provide substantial liquidity support to financial markets and institutions (Bernanke 2009).

The recent crisis is hardly the first time that illiquidity and insolvency have severely damaged the U.S. financial system. Indeed, the financial history of the United States is replete

\footnotetext{
${ }^{1}$ Summers (2000) emphasizes that preventing banking crises depends on avoiding "situations where the bank run psychology takes hold.”
} 
with major banking panics that swept the nation as well as more localized episodes. This paper investigates a previously neglected panic that occurred just prior to the onset of the Great Depression, one which sheds light on how panics develop and spread and how different lenderof-last-resort actions can contribute to ending them. In April 1929, a Mediterranean fruit fly epidemic struck the citrus crop in Florida (a remarkably clear shock that started this episode). In order to prevent its spread to other states, the government quarantined Florida citrus shipments and destroyed infested groves. Over the course of that spring, it seemed increasingly unlikely that farmers would be able to repay their crop loans when they came due during the fall. Congress considered compensating Florida farmers for their losses, but recessed at the end of June without taking action.

The size of losses that farmers would suffer, the effectiveness of the eradication campaign, and whether the government would compensate growers were all unknown. This created uncertainty over the health of bank balance sheets. In July 1929, depositors responded by withdrawing funds from banks, culminating in bank runs in citrus growing areas and the failure of a key correspondent group headquartered in Tampa, Citizens Bank and Trust Company (hereafter Citizens Bank), which served as a financial center for these citrus-growing areas. The solvency shock of the fruit fly infestation had developed into a liquidity crisis as well. To halt the panic, the Federal Reserve Bank of Atlanta shipped large sums of currency to the vaults of the two remaining large correspondent banks in Tampa on July 17 and 18, and publicly promised to provide enough cash to cover all deposits at member banks. By July 20, the run had subsided.

We have assembled a new micro-level database on commercial banks in Florida that allows us to show that deposit outflows prior to the banking panic in July were heaviest in areas subjected to the quarantine - evidence consistent with concerns that the fruit fly and the eradication program were directly affecting banks. Data on Florida's bank correspondent networks allows us to then demonstrate how the panic then spread. Deposit withdrawals at banks in the citrus growing areas put pressure on major correspondent banks. Correspondent banks were 
important liquidity providers, and we show how pressure on the major correspondent banks impacted other banks. The evolution and nature of the Florida banking panic is consistent with models emphasizing how factors affecting the asset side of bank balance sheets, such as uncertainty over payoffs or delays in investment projects, can trigger bank runs (Morris and Shin 2000, Diamond and Rajan 2005) as well as those emphasizing linkages through bank networks (Allen and Gale, 2000).

This response of the Atlanta Fed demonstrates how bold, transparent, and targeted liquidity support by central banks can be vital in halting the spread of a panic and altering depositor confidence during a crisis even when the root of the crisis is clearly a solvency shock. Archival evidence from the minutes of the Federal Reserve Bank of Atlanta (the Atlanta Fed) shows that officials at the reserve bank were concerned with the panic spreading to institutions they viewed as solvent after 8 percent of the state's banks failed within 48 hours of the closure of Citizens National Bank. Officials rapidly provided unconventional liquidity support in Tampa to key banks whose closure they believed would result in a further wave of bank failures. We show that the response by the Atlanta Fed appears to have successfully stemmed the banking panic, changed depositor expectations, and prevented other institutions from failing.

To get a sense of the importance of the intervention by the Atlanta Fed, we use individual bank balance sheet data on the population of Florida banks to construct several counterfactuals. We estimate that bank failure rates would have been twice as high in Florida without the Atlanta Fed's decision to provide funds to the key correspondents in Tampa that were facing runs. Additional results suggest that the intervention likely prevented banks from exhausting their liquid reserves, again helping to arrest the panic.

Finally, the Atlanta Fed's response to the panic in Florida illustrates some of the tools that were available for responding to liquidity crises on the eve of the Great Depression, and how policymakers at one of the regional Federal Reserve Banks viewed their role as a lender of last resort. The Atlanta Fed's response is particularly noteworthy since the Federal Reserve has been 
criticized for not responding to the banking panics of the 1930s and for having little or no experience acting as a lender of last resort during the Great Depression (Friedman and Schwartz 1963). Given the actions of the Atlanta Fed in 1929, the response by the Federal Reserve to the banking panics in the 1930s, or lack thereof, is that much more intriguing.

The next section of the paper describes the events that triggered runs on the Florida banking system in the summer of 1929 and relates it to the theoretical literature on banking crises. Section III then describes the policy response of the Federal Reserve Bank of Atlanta after the failure of Citizens Bank. Section IV analyzes of the causes of bank distress and the effects of lender-of-last-resort intervention. Section V concludes.

\section{The Fruit Fly Infestation and Bank Runs}

To understand how a solvency shock associated with the quarantining of fruit-fly-infested areas spread into a mid-1929 banking panic in Florida, we first discuss the Mediterranean fruit fly infestation that began in April of that year. We then provide an accounting of the bank runs and the response of the Federal Reserve Bank of Atlanta to the banking distress.

\section{A. Florida Citrus and the Mediterranean Fruit Fly Infestation: The Real Shock}

In 1929, Florida's groves contained nearly 9 million orange and 3.5 million grapefruit trees. Revenues from fruit sales totaled $\$ 46$ million, or 51.7 percent of the state’s revenue from crop sales. The largest groves grew in the central peninsula, where the climate protected crops from freezing weather and transportation networks linked orchards to worldwide markets (Figures 1 and 2).

On April 2, 1929, an inspector for State Board of Agriculture discovered grapefruits containing larvae of the Mediterranean fruit fly. Scientists at the USDA Headquarters in Washington, D.C. confirmed the diagnosis on April 10 (Los Angeles Times, May 26, 1929). Florida’s agricultural authorities reacted rapidly. Emergency inspections discovered fruit fly 
infestations in Lake, Orange, and Seminole counties (Figure 3), with particularly dense concentrations around the city of Orlando. The infestation later spread as far north as Ocala County and as far south as Osceola County (Figure 4). By July 1929, the Department of Agriculture estimated that approximately 34 percent of the state's land, containing nearly 75 percent of all the citrus growing trees in Florida, had been infested.

The Mediterranean fruit fly posed a serious threat to agriculture throughout the United States. Although it preferred to consume fruit, the Mediterranean fruit fly ate a wide array of crops, including 72 of the 80 principal fruits and vegetables grown commercially in North America in the 1920s. Its lifecycle allowed it to spread rapidly once it gained a foothold. Generations matured in two to four weeks and the fly had no natural predators or parasites in the U.S. In regions where the fly had become endemic, including Australia, Bermuda, Brazil, South Africa, Spain, the West Indies, Hawaii, and nations around the Mediterranean, farmers were forced to abandon commercial cultivation of most fruits and vegetables.

State and federal governments therefore reacted swiftly to the outbreak. Florida immediately quarantined areas around infected orchards and prohibited shipments of fruits and vegetables. Florida's governor mobilized National Guard troops to enforce the quarantine. All vehicles passing out of the quarantine area were disinfected by washing the exterior and spraying insecticide in the interior of them. The federal government imposed a broader quarantine, including inspections of all trains leaving the state. The United States Department of Agriculture dispatched 20 scientists and several hundred workers to aid the eradication effort. California, the other major citrus growing state, also dispatched a contingent. Eventually, more than 5,000 people worked in the eradication campaign (Los Angeles Times, July 21, p.1 and July 22, p.1).

Officials devised a multilayered defense. Zone 1 was the territory one mile around an infested orchard, and within this area, authorities destroyed all orchards, crops, and wild plants in which the fly might reside. To kill the larvae, laborers burned all fruit found on the ground or buried the fruit at least three feet deep and covered it with motor oil and disinfectant. To kill adult 
flies, workers fumigated infested areas with arsenic sprays or mercury smoke. Authorities imposed Zone 1 restrictions on over 400 independent infestations, mainly in the center of the state, encompassing over 17,000 acres of citrus groves (Figure 4 shows counties with orchards designated Zone 1). Zone 2 stretched for a radius of nine miles outside Zone 1 . All fruit on the vine was destroyed and previously picked or processed fruit could not leave Zone 2 without rigorous inspection and certification as pest free. Zones 1 and 2 covered half of the citrus-growing acreage of the state. Zone 3, encompassing most of the rest of the state, required inspections of all fruits and vegetables prior to harvesting and/or shipment.

Neighboring states also reacted rapidly to the fruit fly infestation. Eight southern and ten western states banned the importation of fruit and vegetables from Florida (Los Angeles Times, June 23, 1929, p.5) as did many foreign nations - including Canada, Chile, Cuba, Jamaica, Mexico, Spain, the Dominican Republic, and the Bahamas.

The embargoes, eradication, and quarantine took its toll on Florida's agricultural industry. Fruit production in the affected areas fell by sixty percent. Growers suffered devastating losses, including years of investment in trees and infrastructure. Congressional contingents from Florida and California therefore proposed Federal relief for farmers forced to destroy crops and trees. Under this plan, the federal government would pay part of the losses of the growers. The state government would contribute a similar portion, and the farmer would absorb a smaller amount. Secretary Hyde of the Department of Agriculture endorsed the plan and recommended that Congress appropriate \$10 million for the task with the provision that the Federal government pay at most half of the amount given to growers (Los Angeles Times, June 21, 1929, p. A20). ${ }^{2}$

Agricultural committee's in the House and Senate debated the issue in April, May, and June. Congressmen from states in the Great Plains opposed compensating Florida's farmers

\footnotetext{
${ }^{2}$ The proposed $\$ 20$ million of total aid to growers (\$10 million from the federal government and \$10 million from the state government) would have amounted to nearly 40 percent of owners' equity in Florida's commercial banks (using data from the end of June, 1929). As we describe later, Florida's citrus growers never received this money.
} 
unless the government considered similar compensation for losses that grain farmers incurred from recent infestations of other pests. In the last week of June, with the issue unresolved, Congress adjourned for the summer recess. A newspaper columnist observed that "there is much disappointment... at the failure of Congress to grant a relief appropriation before it went into recess. Many growers will find it extremely difficult to hold out during the interim until August when Congress will reconvene. Nor is it certain that an appropriation will be made then (Los Angeles Times, June 28, 1929, p. 1).”

Reimbursement for losses, however, did not materialize in the month of July, which created uncertainty as to whether citrus farmers would be able to repay their loans and stoked fears that banks that lent heavily to growers and processors were insolvent and become so. Congress continued to debate restitution to growers for more than a decade; the Senate was still holding on the issue in 1940.

\section{B. Florida Bank Suspensions in 1929 and the July Banking Panic}

Florida’s commercial banks had weathered three severe shocks in the 1920s. First, crop prices fell dramatically after World War I, and many farmers who had expanded production during the war, defaulted on real estate loans. Then, in 1925, Florida's real estate bubble burst; property values plummeted and deposits at banks declined by fifty percent. Finally, Florida was hit by two severe hurricanes - one in 1926 and another in 1928 - which resulted in significant property damage (more than $\$ 1.28$ billion in 2008 dollars) and loss of human life. While these financial and meteorological storms affected the balance sheets of some banks, some commentators suggested that by 1929 Florida’s banking system had fully recovered. “The banks of Florida have increased their capital and surplus by 35 percent [as compared to the peak of the boom in 1925], have charged off all losses, and regularly have paid dividends ... Florida banks 
[are] in a more liquid condition, having more cash as compared with total resources, than ... any other banks in the nation (Wall Street Journal, January 19, 1929, p. 11).”

It was with these initial conditions that the Florida banking system entered 1929 and subsequently experienced 64 bank suspensions. The 1929 Annual Report of the Federal Reserve Board (p.22) stated that the Atlanta Fed had the largest number of suspensions and fastest growth rate in suspensions in the country for that year. It further reported that the increase in failures in the Atlanta region was almost entirely driven by a surge in bank failures in Florida and concluded that: "In Florida, the suspensions were due largely to the inability of the banks to realize on slow assets acquired in prior years, apparently aggravated by heavy withdrawals brought about by the disturbance in the fruit industry resulting from the destruction wrought by the Mediterranean fruit fly."3

Figures 5 and 6 show the timing and geographical distribution of commercial bank failures in Florida. The first batch of bank failures occurred in February. Between the 11th and 18th of the month, the state comptroller closed six banks after examiners detected problems due to financial improprieties. These banks shared common management and all of the institutions had loaned large sums to the managers and directors of this "group bank.” These individuals were unable to repay and the banks were closed. The second cluster of bank failures occurred one month after the fruit fly invaded Florida's orange groves. Between May 15 and 18, seven banks failed in the citrus-growing region.

The third and largest cluster of bank failures occurred in July (Figure 5). The Federal Reserve Bank of Atlanta became increasingly concerned with the possibility of widespread distress in Florida by June. Discussions of these concerns and the actions taken are described in the minutes of the meetings of the Board of Directors of the Federal Reserve Bank (hereafter Atlanta Board Minutes). By the middle of June, the Atlanta Fed received a request from Citizens

\footnotetext{
${ }^{3} 16^{\text {th }}$ Annual Report of the Federal Reserve Board (1929, p.30)
} 
Bank, which was a correspondent to many other banks in the citrus growing center of the state, to rediscount eligible and acceptable paper from certain nonmember banks that were a part of its banking group for a period of six months “....as a result of the unsettled conditions in Florida, and particularly in those sections affected by the Mediterranean fruit fly.” The Board of the Atlanta Fed, concerned that a banking panic could spread through correspondent networks, of which Citizens’ Bank was a key part of, quickly approved Citizens’ Bank request at their June 14 meeting, and sent it on for Federal Reserve Board approval, which granted it on June 17 (Atlanta Board Minutes, June 14, 1929, p. 1597 and July 12, 1929, p.1607). ${ }^{4}$

Nevertheless, withdrawals from banks in the center of the state are described as accelerating at the end of June after Congress adjourned without indemnifying losses caused by the fruit-fly infestation. Delaying the decision crimped growers' cash flows, raised the possibility that growers might not repay their crop loans, and threatened the viability of financial institutions that loaned large sums to citrus growers. ${ }^{5}$ Bank directors closed two banks on June 28, the day that Congress adjourned. ${ }^{6}$ Six other banks closed in the following week. According to materials from the Federal Reserve archives, all of these banks had frozen loans. ${ }^{7}$ Five had experienced heavy withdrawals. Two of the six had faced financial difficulties after their correspondent bank closed its doors. In comparison to one year earlier, deposits of Fed member banks in Florida had fallen by $\$ 38.5$ million as of June 30, a decline of 16 percent (Atlanta Board Minutes, August 9, 1929, p. 1616). Recognizing that the position of commercial banks was worsening in Florida and anticipating that it could grow more serious, on July 12, the Board of Directors of the Atlanta

\footnotetext{
${ }^{4}$ Citizens Bank was also the head of a group of banks in which the majority shareholders in Citizens also owned controlling shares in these other banks. There also appear to have been other linkages, such as correspondent relationships, among these institutions. Unless otherwise noted, the banks that were part of the Citizens Bank group (but not Citizens Bank) are dropped from the sample as their failure is not likely to be independent of the failure of the lead bank.

${ }^{5}$ Although it is impossible to measure the direct effect of this on the banking system, the value of the citrus crop was equivalent to about 22 percent of the value of all commercial bank loans in Florida.

${ }^{6}$ Neither of these banks received injections of capital from investors to keep them solvent (Federal Reserve of Atlanta archives, Minutes of the Board of Directors, July $12^{\text {th }}$, 1929, p.1606.)
} 
passed a resolution authorizing "revolving currency funds” or “currency depots” in Miami and Tampa for six months or "for as much time as deemed necessary" to "relieve emergency situations as may occur”:

Whereas the directors of the Federal Reserve Bank of Atlanta believe that the present emergent conditions in the State of Florida make imperative the establishment of currency revolving funds of $\$ 1,000,000$ each to be placed respectively in the cities of Miami and Tampa, to the end that member banks in the said two cities, or in the vicinity thereof, may readily obtain supplies of currency as urgent need therefore may arise. (Atlanta Board Minutes, July 12, 1929, p. 1607)

Currency funds were established by the Federal Reserve to permit banks quick access to currency — typically in areas were large numbers of cash payments needed to be made or in areas where financial distress was anticipated-and the Federal Reserve expected it would take too long to ship currency from the Reserve Bank. The proposed currency revolving funds entailed placing large amounts of currency at "custodian banks,” with the Federal Reserve maintaining legal possession of the currency. In return, the custodian banks would provide the Federal Reserve with collateral, in this case, U.S. government securities. Currency could be withdrawn from the funds by Federal Reserve member banks in cases where cash was being sent to that bank through the Federal Reserve—-such as via wire transfer administered by the Federal Reserve or as part of a discount window loan-but the currency had not yet arrived when it was needed. Once the currency arrived it would be used to replenish the fund (Federal Reserve Board of Governors 1938). ${ }^{8}$ The Atlanta Fed's resolution authorizing these funds was immediately sent to the Federal Reserve Board of Governors for approval. The Board of Governors replied on July 16, stating that the revolving currency funds could be established once the Board received the names of the

\footnotetext{
${ }^{7}$ We refer here to reports compiled by the Federal Reserve Board of Governors, Division of Bank Operations, which provide information on the reasons that banks were closed. We describe these reports in detail below.

${ }^{8}$ Federal Reserve approval was needed to before funds could be withdrawn. The custodian banks were liable for losses associated with the revolving currency fund.
} 
member banks, which would serve as custodians of the funds (Atlanta Board Minutes, August 9, 1929, p.1626). ${ }^{9}$

Despite the Atlanta Fed's initial attempts to alleviate distress by allowing nonmember banks to rediscount through member banks, the withdrawals proved too great for key correspondents in the citrus areas to handle on their own. Steady withdrawals by country banks were straining correspondents in Tampa, the financial hub of the citrus industry. ${ }^{10}$ The large correspondent banks in Tampa held reserves of smaller country banks operating in the citrusgrowing regions. Country banks had to draw down their reserves as depositors steadily withdrew funds. Country banks were likely unable to raise cash by selling assets because most of their assets were loans to local farms and businesses and were frozen by the fruit-fly situation. On July 17, 1929, country-bank withdrawals forced the directors of the Citizens Bank, an institution with deposits of $\$ 13,695,871$, to suspend operations. Citizens Bank had lost a substantial share of its deposits in the previous three weeks and had discounted most of its eligible assets $(\$ 1,884,051)$ at the Federal Reserve discount window. The suspension of the Citizens Bank triggered runs at banks throughout Tampa and nearby municipalities as well as at institutions belonging to the Citizens Bank Group. Newspaper accounts stated that "frozen assets from the Florida real estate boom and the inability of citrus growers and truck farmers to meet their obligations after the invasion of the Mediterranean fruit fly, and the quarantine against the State, are blamed for the closing of the banks (Financial Chronicle, Saturday, July 20, 1929, p.422).”

While the runs were in progress, lines of panicked depositors grew outside of all banks and "business was practically at a standstill in Tampa” (New York Times, July 18, 1929, p.1). Within 48 hours, 18 banks closed their doors (8 percent of the state's banks). Many were either

\footnotetext{
${ }^{9}$ One could think of rediscounting paper for Citizens Bank and its Bank Group as an effort to provide support to a particular institution while the revolving currency fund was a general program that could provide liquidity support to a number of institutions.

${ }^{10}$ A 1939 WPA study of 67 medium-sized bank suspensions suggests that correspondent banks were particularly vulnerable to deposit outflows. During the banking panics of 1930 and 1931, interbank deposits declined precipitously. "In most of the banks demand deposits showed somewhat larger percentage
} 
members of Citizens Bank Group or respondents of Citizens Bank, but several nonaffiliated institutions closed as well. Florida Banking Superintendent Amos stated on July 17 that the causes of the failures were "unnecessary withdrawals, propaganda, and the mental attitude of the people. There is a financial depression to a certain degree everywhere in the State which has been accentuated by the effect of the Mediterranean fruit fly and quarantine. I regard this as the darkened hour just before the dawn, however, if the people will not tear down the temple upon their own hands. This is what they are doing now" (Financial Chronicle, Saturday, July 20, 1929, p.422). During the next week, runs forced seven more banks out of operations. Runs spread throughout the state, striking the cities of Gainesville, St. Augustine, St. Petersburg, and Orlando, where, in the latter two cities, banks invoked their right to require 60-day notice for withdrawals from savings accounts. Further, the Atlanta Fed noted that the runs were affecting banks they considered sound; "That the loss of confidence is not confined to depositors of the weak banks in Florida is evidenced by the runs upon the St. Augustine National Bank and the First Bank of Gainesville” (Atlanta Board Minutes August 9, 1929, p. 1621). What had started as a concern over the solvency of banks appears to have added a severe liquidity dimension by mid-July.

\section{Closing Banks during the Panic}

During the summer of 1929, nearly all the bank suspensions resulted in banks being put into liquidation by regulators, and hence were classified as bank failures. The primary reason for the banks being put into liquidation had to do with the procedure used by Florida bank regulators to deal with banks that closed their doors, even temporarily. Florida's banking law required examinations of all banks that ceased making payments to depositors (or other creditors). Banks that could demonstrate solvency, sound reasons for suspending payments, and the ability to reopen when the crisis passed were permitted to keep their doors closed temporarily. Banks that

reductions than time deposits, and interbank deposits showed much sharper reductions than either demand or time.” (Federal Reserve Bulletin, March 1939, p.178.) 
could not prove these points were placed in receivership. Since Florida banks had trouble proving the first two points in the spring and summer of 1929, they were liquidated. ${ }^{11}$

The typical Florida bank placed half of its assets in loans and discounts, most of which financed the revolving credit needs of local businesses. The fruit fly infestation reduced the value of these loans since the likelihood of repayment depended on the success of the eradication campaign and on the potential for growers' to be compensated for their losses, neither of which was certain during the spring and summer of 1929. Examiners marked most of these loans at their liquidation value, which under the circumstances fell far short of book value.

The typical Florida bank placed about one-fifth of their assets into bonds. Banks used bonds to diversify their portfolio, and usually purchased obligations from governments and corporations outside of their vicinity. While the fruit fly infestation had little impact on the value of this portion of Florida's bank's portfolios, economic events conspired to drive down bond prices at this time. As the stock market soared in 1928 and 1929, money flooded into equities and out from other investments. Bond prices fell and yields rose with the yield on short-term U.S. government rising from 3.09\% in January 1928 to 5.09\% in May 1929.

So, banks that suspended operations during the fruit-fly panic faced scrutiny of their balance sheets at a time when the bulk of their assets had depreciated in value. Rules required examiners to mark these assets at their market or liquidation value. These markdowns turned almost all suspensions into bankruptcies when bank regulators turned their charges over to the courts, the agency which supervised receiverships and liquidations of banks in Florida.

\footnotetext{
${ }^{11}$ Upham and Lamke (1934) note that regulators of both state and national banks required banks to mark bonds and securities to market. Rigorous evaluation of closed banks was especially likely to have been the case in Florida where Dovell (1955) reports legislation had been passed in 1927 and 1929 at the behest of
} 


\section{Discussion}

The evolution of the Florida banking panic appears consistent with some recent theoretical models. In Morris and Shin (2000) and Goldstein and Pauzner (2002), depositors receive a noisy signal regarding the health of a financial institution. Based on this signal and their beliefs about the actions that other depositors might take, depositors decide whether to withdraw. The distribution of signals determines whether a bank experiences a run. A unique run/no run equilibrium outcome is determined by the distribution of signals. In these models, there are levels of signals where the bank clearly survives or fails, but also a region where the equilibrium is selffulfilling in the sense that a bank would be forced to liquidate assets inopportunely and become insolvent if there is a run or remain solvent if there is no run.

During the Florida panic, there appear to have been signals that caused depositors to withdraw their funds. In citrus growing areas, the signal was the potential losses due to the infestation and the lack of government reimbursement following the eradication. For Tampa, the signal appears to have been the closure of Citizens Bank, which was an indication that banks with strong ties to the citrus growing region or with large correspondent networks were vulnerable. As the panic dissipated in the face of liquidity rather than solvency support, it suggests that there may also have been some self-fulfilling aspects to the runs.

Some theoretical work building on Morris and Shin (2000), such as Atkeson (2002) and Hellwig, Mukherji, and Tsyvinski (2006), argue that, in some situations, it is possible for multiple equilibria to emerge if there is something that generates common knowledge, like an interest rate that can act as a coordinating mechanism. The panic episode studied in this paper points to some reasons why a coordination mechanism might not emerge. Banks in Tampa suffered withdrawals from both their respondents and local depositors, groups with very different information sets that were geographically segmented. These features would likely have made information gathering

the State Banking Comptroller to strengthen the ability of the Comptroller to close banks and oversee the liquidation process. 
and sharing quite costly and time consuming, so it is unlikely that the deposit rate acted as a coordinating device. Individual depositors were likely focused on getting their cash out of bank and were preoccupied with bank survival. Even during this time period, the run seems to have occurred with considerable speed.

The spread of the crisis through the correspondent networks is similar to some of the recent theoretical work by Allen and Gale (2000), who emphasize linkages that can transmit panics. They show that if bank networks are incomplete, then solvency shocks in one area can generate liquidity problems and then solvency problems in other areas. This idea matches the observation that runs spread from banks in the citrus growing areas to Tampa where the focus of concern appears to include the potential impacts from the failure of other banks.

\section{The Atlanta Fed's Response following the failure of Citizens Bank}

The Federal Reserve Bank of Atlanta responded quickly to the failure of Citizens Bank and the subsequent bank runs. The New York Times reported that the Atlanta Fed flew $\$ 1,000,000$ in cash to Tampa on July 17 and delivered an additional \$5,000,000 the next morning. This currency was likely connected with the establishment of the revolving currency fund. Federal Reserve officers reportedly delivered the funds to the First National Bank and Exchange National Bank, the two institutions named as custodians of the currency fund, which remained open but faced runs in the wake of the closing of Citizens Bank. ${ }^{12}$ These two institutions had significant correspondent networks, maintaining correspondent relationships with 31 and 19 other banks, respectively. At both of these institutions, long lines of customers were waiting to empty their accounts. "Both [banks] withstood the runs, but when they closed their door this afternoon throngs were still around the buildings seeking to get to the tellers' windows to make withdrawals” (New York Times, July 18, 1929, p. 1). Creed Taylor, Deputy Governor of the 
Atlanta Reserve Bank arrived in the afternoon of July 17. The Fed official was quoted by the newspapers as stating that the reserve bank was "prepared to send enough money to pay every depositor of the First National and the Exchange National if necessary,” that the reserve bank "would send addition millions if needed and will be used to establish a currency depot” in Tampa (New York Times, July 18, 1929, p. 1).

According to newspaper accounts, when the second shipment of Fed money arrived, the runs on the two Fed member banks in Tampa subsided: "while a number of depositors withdrew their money, the bank officials reported, at closing time, that the deposits during the day had exceeded withdrawals...Indications were that confidence had been restored and that in the next few days most of the money withdrawn yesterday and today will be returned to the vaults of the banks. The arrival of \$5,000,000 here today and yesterday from the Atlanta Federal Reserve Bank and the sight of the money in huge stacks in the cages of the bank tellers had a reassuring effect. Crowds about the banks were much smaller than yesterday and were there out of curiosity.... run continued in Ybor City, but officials were able to meet all demands by depositors” (Financial Chronicle, Saturday, July 20, 1929, p.422).

The intervention in Tampa illustrates the bold response of the Atlanta Fed to a run on the banking system. First, the Bank’s policy was highly visible and transparent: high-ranking Reserve Bank officials came to the scene of the panic to reassure depositors that their accounts were safe. Second, the policy response was overwhelming rather than incremental in the sense that large amounts of cash made were immediately made available. The board minutes of the Atlanta Fed indicate that between the start of the crisis in July and the second week in August, more than \$25 million of currency was shipped to Florida to deal with the banking crisis (Atlanta Board Minutes, August 9, 1929, p. 1624). Third, the response was direct and targeted to the institutions

\footnotetext{
${ }^{12}$ The minutes of the Atlanta Fed's discount window committee indicate that Exchange National borrowed a bit over $\$ 1,000,000$ on July 20, 1929 through the discount window. It is possible that the cash related to this loan was drawn from the revolving currency fund.
} 
at the center of the crisis. Comments from Governor Black in the August board minutes make the

Atlanta Fed's strategy clear:

Attention should be called to the runs upon the First National Bank of Tampa and the Exchange National Bank of Tampa, as reflecting the loss of confidence of the citizens of Tampa following the closing of Citizens Bank and Trust Company. There were large runs upon both the First National Bank of Tampa and the Exchange National Bank of Tampa. Deputy Governor Taylor was present during these runs and aided in every way that he could in supplying necessary currency. Large sums were sent by airplane by the Jacksonville Branch and large shipments were made by mail. On the first day of the run upon these two banks $\$ 1,700,000$ was withdrawn from the First National Bank and approximately $\$ 1,200,000$ from the Exchange National Bank. It is gratifying to note that both of these good [italics added] banks remained open and that their deposits have been flowing back to them. (Atlanta Board Minutes, August 9, 1929, p. 1621.. ${ }^{13}$

The Atlanta Fed's actions in Tampa seemed to have been perceived by investors to have been credible as the bank runs were arrested. The liquidity support provided by the Atlanta Fed in this episode appears to have had some local precedent. Garrett (1956) describes a crisis of confidence following the collapse of the Manly-Witham chain during which the Atlanta Fed in 1926 lent heavily to support Polk County National Bank of Bartow, Florida; this bank was reportedly seen as a "key bank” whose failure might trigger other failures (Garrett, 1956, Chapter 15). The actions taken in Florida in 1929 were also similar to its response to a bank run in Cuba in 1926 (where the Atlanta Fed operated an agency). In that instance, the Atlanta Fed, in conjunction with the Board of Governors and the Boston Fed, rushed over \$30 million in cash to Havana, and helped member banks extend credit to correspondents. Newspaper accounts credited this intervention with stopping depositor withdrawals. ${ }^{14}$

Compensation for growers never materialized, but optimistic prognostications concerning cultivation eventually bore fruit. Before the panic in July, newspaper accounts had predicted the widespread destruction of groves, massive losses to citrus growers, a multiyear effort to eliminate the pest, and the wholesale destruction of the citrus industry. The eradication campaign

\footnotetext{
${ }^{13}$ Federal Reserve of Atlanta archives, Minutes of the Board of Directors, August $9^{\text {th }}$, 1929, p.1621.

14 Garrett, 1956, Chapter 15; New York Times, "Money Being Rushed to Cuba,” April 11, 1926, p.15 and New York Times, "Stocks hit Here as Cuba Recovers,” April 13, 1926, p.8.
} 
intensified over the spring and into the summer as additional resources reached the region and experience gained over the preceding months on how to destroy the pest increased the efficiency of those on the front lines. After July 15, "no trace of the pest [was] found in Orange county, Fla., the territory most heavily infested," and new methods of eradication enabled "the destruction of the fly without the loss of valuable groves” (Los Angeles Times, August 8, 1929, p. 11). After September 1, 2009, the Federal Government eased the quarantine and allowed fruit to be shipped from orchards more than 10 miles from the nearest infestation.

Even though the call money market remained tight in the last week of July, the New York Times reported that the Florida banking crisis had hit rock bottom by the end of the month (New York Times, July 25 and 28). Evidence from our bank failure series suggests it took until the end of August for the solvency shock associated with the fruit fly to work its way through the banking system.

\section{Empirical Analysis of the Florida Panic}

In order to understand the effects of the real shock on the Florida banking system, the subsequent liquidity crisis, and the Fed's response, we assemble a new micro-level database on commercial banks and bank failures in Florida for 1929. We construct a data panel consisting of all banks that operated in Florida between January and December 1929, which follows individual bank performance over the year. Our panel contains standard information about bank characteristics (such as balance sheet information) and economic conditions (such as levels of farm indebtedness and the condition of the citrus crop) as well as measures of financial distress (suspensions and liquidations), all changes in bank status (mergers, consolidations forced by financial difficulties, and voluntary liquidations), and paths of contagion (correspondent linkages, runs on banks, and geo-coded data showing banks in counties impacted by the quarantine). Balance sheet data, correspondent relationships, Federal Reserve membership and other individual bank characteristics comes from the Rand McNally Bankers' Directory and Polk's 
Bankers Encyclopedia. Rand McNally is published biennially January and July and Polk's is published biennially in March and September. Data on Florida and the characteristics of its counties, which we link to individual bank data, comes from the United States Censuses of Agriculture, Manufacturing, and Population.

Three independent sources enable us to determine the dates and the nature of Florida's banking crisis. The Board of Governors', Division of Bank Operations on Form St. 6386b, reports individual bank suspensions and their causes. Form St. 6386c reports changes in bank status, such as re-openings of suspended institutions and voluntary liquidations, a category of closures in which banks ceased operations and arranged to repay depositors the full value of their deposits without the intervention of courts or receivers. These data distinguish between temporary and permanent closures of banks. A temporary suspension occurred when a bank closed its doors to the public for at least one business day even if the bank later reopened for business. Permanent liquidations were the subset of suspensions where insolvent banks permanently ceased operations, surrendered charters, sold assets, and repaid creditors under the auspices of a court appointed officer called a receiver. The second source is the narrative description of events contained within the biennial reports of Florida's state banking department. The third is articles in newspapers and periodicals including the Atlanta Journal, New York Times, Los Angeles Times, Wall Street Journal, and the Commercial and Financial Chronicle.

The correspondent networks play an important role as the transmission mechanism and Table 1 provides some summary statistics of these relationships. We define a major correspondent as any hub institution that had at least seven respondents (banks that received clearing, liquidity, and other services from the correspondent). There are nine such institutions in Florida at the start of 1929, located in a few major cities. All but a handful of banks had relationships with at least one of these institutions and many had multiple relationships. The table also shows that about half of the banks that used Citizens bank as a correspondent also had a relationship with at least one other institution, suggesting how the failure of Citizens Bank could 
have been a source for contagion and bank runs. Many of the major correspondent banks had respondents located in the areas subject to the quarantine, although Citizens Bank had the largest share of respondents in these areas.

\section{A. Deposit Analysis}

To provide some insight into the evolution of the crisis, we make use of the unique data we collected on deposits and correspondent relationships. We first document that deposit outflows are most significant in areas that were clearly affected by the quarantine. As banks in these areas were exposed to the initial solvency shock, it would be natural for risk-averse depositors or other banks to remove some of their funds from these banks. This is what we observe. Table 2 shows that deposit outflows from March until June were much greater in areas where the eradication efforts were centered than in other areas.

The historical record suggests that these country banks began drawing down reserves in Tampa banks as depositors in citrus-growing areas steadily withdrew funds. As described above, Citizens’ Bank, with deposits of more than \$13 million, suspended operations on July 17, 1929 as a result of deposit withdrawals, which then triggered runs on other banks in Tampa and the surrounding areas.

Deposit data again shed light on the pressure that the key correspondent banks in Tampa were facing. Table 3 shows that the Citizens Bank Group faced a large drain on its deposits between March 1929 and either June 1929 or the date member of the bank group closed (the interval for which we have data). Correspondents of Citizens Bank that were not a part of the group also saw sharp declines in deposits, though not as large as members of the group. These declines were much more pronounced than declines at banks not affiliated with Citizens Bank, showing that the pressure this institution was facing and suggesting why it sought succor from the Atlanta Fed. Even prior to the failure of Citizens, the two other major national banks in the city, 
Exchange National of Tampa and First National of Tampa, and their correspondents also faced significant depositor withdrawals (Table 4).

Another type of financial institution that existed in Florida in 1929 provides additional perspective on the spread of the panic. During the crisis, Florida's 68 building and loan societies (B\&Ls) experienced few withdrawals and no failures. Nevertheless, B\&Ls faced substantial exposure to agricultural shocks because the majority of their investments were tied to local real estate, whose value would decline if farmers could not sell crops. However, B\&Ls lacked exposure to contagion since they did not rely on the commercial banking system's correspondent network in a significant way. B\&L deposits at correspondent banks were small and they did not rely on them for check clearing. B\&Ls also lacked exposure to sudden depositor withdrawals because they did not possess demand deposits. They offered only time deposits, in the form of mutual shares or certificates of deposit, and these required 30-days' notice prior to withdrawal. Shocks which might have forced building and loans to cease operations would have thus resulted in lower share prices for all members (Comptroller of Florida, 1929 to 1931).

Newspaper accounts and the minutes of the Atlanta Fed indicate that pressure on Exchange and First National increased substantially following the failure of Citizens Bank. Calculations based on figures from the Atlanta Fed's minutes suggest that Exchange National and First National saw their deposits decline by 11 and 12 percent, respectively, on the first day of the panic. ${ }^{15}$ If deposit withdrawals had continued at this rate, Exchange National Bank would have exhausted its ready reserves (cash plus bankers' balances) on the second day of the panic, and it would have run out of securities that could have been sold and loans that could have been discounted on the fifth or sixth day of the panic. First National Bank would have lasted almost as long. It would have run out of ready reserves just after lunchtime on the second day, and would have exhausted liquid assets three days later.

\footnotetext{
${ }^{15}$ These calculations compare the declines of $\$ 1,200,000$ and $\$ 1,700,000$ in deposits for Exchange National and First National, respectively, with March (pre-panic) values of deposits.
} 
The Atlanta Fed intervened on July 17 by shipping currency to Tampa and publicly announcing support for institutions under pressure. These efforts appear to have successfully restored confidence in these banks. As shown in Table 4, deposits from June (prior to the panic) through September were little changed at banks having correspondent relationships with the two remaining key banks in Tampa.

\section{B. Did the Fed's Intervention Prevent Solvent Banks from Failing?}

The historical narrative and data on deposits suggests that a banking panic occurred in Tampa in mid-July 1929 and was spreading throughout the Florida banking system. A key question is whether the Federal Reserve's intervention in Tampa mattered such that otherwise solvent banks were able to survive the panic. ${ }^{16}$ We address this question using several counterfactual scenarios.

To construct these counterfactuals, we first determine the probability of failure of individual banks over different time horizons. ${ }^{17}$ We divide 1929 into four periods:

- Period 1: June 26-July 16 - after Congress adjourns with no compensation to citrus growers;

- $\quad$ Period 2: July 17-July 19 - Citizens Bank in Tampa fails, Tampa panic occurs;

- Period 3: July 20-August 5 - following the Fed intervention with support to two Tampa national banks; and

- Period 4: August 6 until the end of the year - the period after last bank fails due to deposit losses and the panic subsides.

\footnotetext{
${ }^{16}$ Records of the Discount Window Committee from the Atlanta Federal Reserve Bank list discount loans made by the Atlanta Fed in 1929. Regression analysis does not find a systematic relationship between discount window loans to banks in Florida in the weeks leading up to Citizens Bank's failure and a change in the failure/survival outcome during the panic period.

${ }^{17}$ We drop banks that were members of Citizens Bank Group from the analysis from here forward as their fate was dependent on that of the main bank.
} 
We estimate a logit regression using individual bank data that includes information regarding the correspondent relationships (which we argue served to transmit the shock), exposure to the fruit fly eradication program, and the expected probability of survival from a first-stage regression using pre-crisis period characteristics. The second-stage logit regression takes the form:

(1) Fail/No Fail = f (period, major correspondent in Jacksonville, period*major Florida nonJacksonville correspondent, period*major Florida non-Jacksonville correspondent fails, other bank in county experiences a run in current or preceding period, quarantine zone county, period*expected survival probability from first stage.

We divide the major correspondents into those in Jacksonville and outside Jacksonville because there was a branch of the Atlanta Fed located in Jacksonville, so concerns about liquidity issues and the response to Federal Reserve liquidity provision programs may have operated differently there. Since we are interested in estimating the effects of the major correspondents on respondents, we exclude these 9 banks from the estimation. Of the major Florida correspondents, Citizens Bank is the only one that failed in 1929.

To construct the first-stage regression, we use balance sheet information from all Florida commercial banks in existence in January 1929 to examine whether these bank characteristics were good predictors of failure in the pre-crisis period. Our predictors for suspension are (log) total assets, interest-earning assets as a share of total assets, bonds and securities' share of interest-earning assets, net worth to total assets, liquid deposits, the (log) age of the bank, and the population of the town where the bank is located. Table 5 shows logit (maximum likelihood) estimates of the probability of suspending prior to June 26 (just before Congress adjourns without appropriating funds to reimburse orange growers and before the banking panic begins) based on 1929:Q1 characteristics.

Generally consistent with previous studies, the results from the first-stage regression show that that, all else equal, banks were less likely to suspend when they held more bonds relative to loans (bonds tended to be less risky and more liquid), were older, and were located in a 
larger town. Banks with more cash on hand relative to deposits were also less likely to close. These regressions reveal that measures of bank health (reflecting solvency, liquidity, portfolio risk, and owner's exposure among other factors) were correlated with failure in much the same way as other studies of bank failures during this period (Calomiris and Mason 1997, 2003; White 1984; Carlson 2010).

These failure regressions establish a baseline that we use in the second stage to provide an indicator of the health of each bank coming into the banking panic. That is, since these regressions use balance sheet data and failure information from the period prior to the panic, we use the predicted probabilities of survival from them as ex ante measures of the condition of each bank on the eve of the panic.

Regression results estimating equation (1) are shown in Table 6. As one would expect, given the source of the shock, being in a county in which the infestation occurred increased the likelihood of failure. The expected survival probability from the first-stage regression also tends to decrease the likelihood of failure, suggesting that banks that were healthier before July were less likely to fail. We find that being in the vicinity of bank runs is associated with an increased likelihood of failure. Overall, the regression reasonably predicts failure over the year. The average predicted probability of failure conditional on the banks failing is 15 percent whereas the average predicted probability of failure conditional on having survived the panic is 3 percent.

We find that having a major correspondent bank fail notably increased the odds that its respondents would fail. There are a few potential reasons for this finding. First, the major correspondents served as a source of liquidity for their respondents and having this source dry up, especially during a panic, may have prompted some banks to close their doors. Correspondents also provided important clearing services for their respondents and the loss of the correspondent may have negatively affected the business prospects of these institutions. Also, during a panic, 
being a respondent of a failing correspondent bank may have caused concern among other banks or depositors about the health of the respondent and prompted withdrawals. ${ }^{18}$

To consider what would have happened if the banking panic had gone unchecked, we calculate failures for several different scenarios. The first row of Table 7 shows actual failures during the period July 20 to August 5, 1929. The second row shows failures in this period predicted by our regression. The third row considers a scenario where the two key correspondent banks in Tampa (Exchange National and First National) failed. We do this by changing the indicator variable for having a large non-Jacksonville correspondent bank fail from zero to one for banks that used Exchange National or First National as a correspondent and recalculating the expected probability of failure of each bank. (Thus, we assume that the impact of the failure of Exchange National or First National has the same impact on likelihood of failure of their respondents as the failure of Citizens Bank had on its respondents.) We estimate that 14 banks would have failed if the Fed had not intervened - nearly doubling the failures that actually occurred during the crisis period. ${ }^{19}$ Having all non-Jacksonville correspondents fail, the fourth row of Table 7, would have increased failures slightly more. The last row of Table 7 shows the results from a counterfactual scenario where all major correspondent banks-those in Jacksonville and outside Jacksonville-failed, assuming that the impact of a failure of a Jacksonville correspondent would have had the same impact as the failure of other banks. We construct this "upper bound" estimate of the impact of the crisis in a manner similar to the previous counterfactual only with the indicator of a large correspondent failing equal to one for a

\footnotetext{
${ }^{18}$ Others, such as Carlson (2004), have found that the loss of a correspondent bank increases the likelihood that a smaller "downstream" bank will close.

${ }^{19}$ Although we are able to provide some plausible estimates as to how much worse the situation would have been without the policy intervention, we are not able to identify the exact channel by which the Federal Reserve liquidity support mattered. One possibility is that the intervention prevented fire sales and/or mitigated depositor concerns that the banks would be unable to meet deposit withdrawals when needed. A second possibility is that the intervention may have bought depositors time, allowing them to evaluate the quality of banks during periods when asset values were less uncertain and reduce the information problems that can generate runs (Morris and Shin 2000). One might also imagine other channels.
} 
larger set of institutions. Under this extreme scenario, we calculate that 30 percent of all banks in Florida would have failed.

The counterfactuals provides some estimates of further banking distress in Florida absent Fed intervention; however, it is likely that they fail to capture some of the effects that the intervention had on restoring confidence in Florida’s banking system. We know from historical accounts that runs occurred in other cities like St. Augustine and Gainesville, and these ended when the Atlanta Fed intervened (Atlanta Board Minutes, August 9, 1929, p.1621). To what extent, then, did the Fed's action halt deposit withdrawals that would have otherwise led to a fire sale of assets, additional suspensions, and a broader banking crisis? Such a calculation would be straightforward if it were possible to count how many banks ceased having runs after the Fed intervened. Since we cannot determine this figure, we instead compute estimates of banks that would have exhausted cash and liquid reserves for deposit withdrawals of various magnitudes. Once liquid reserves are exhausted by depositor withdrawals, banks might have been forced to call in loans or attempt to dispose of less liquid assets at fire sale prices. However, many of the banks facing runs in July 1929 may have had significant exposure via loans to citrus growers, and since the valuations on these loans was uncertain, it is likely that many if not all of the banks facing deposit withdrawals greater than their liquid reserves would have been forced to suspend.

Table 8 indicates the suspensions or fire sales that would have resulted from deposit losses of various sizes. The calculations are based on June 30 call-report data for state banks and July 1 data for national banks. Banks typically held less than 35 percent of their assets as liquid reserves, so we use this as the highest value in the table: values above this would have resulted in the closure of all banks. Although we present a range of deposit withdrawals in the table, it may be fruitful to think about what value is most plausible. As we have noted above, the key event of the panic was the failure of failure of Citizens Bank Group, which saw deposits fall by 30 percent 
before suspending. ${ }^{20}$ So, assuming deposit declines of 30 percent in our "stress test," we find that more than 50 percent of all banks would have been in a "fire sale" situation or suspended if they only had access to cash. Roughly 6 percent of banks would have suspended or invoked a "fire sale” if they could use all their liquid reserved to fight deposit withdrawals. This means that, even in cases where banks could have drained all their liquid reserves to fight off a run, the number of failures in the panic period would have roughly doubled.

As might be expected, experiences on how quickly banks shut down appear to have depended on how severe deposit losses were prior to the panic in July. Institutions that experienced deposit losses during the spring quarter (after the discovery of the fruit fly and before Congress adjourned at the end of June) closed their doors rapidly once runs began. Others were reported to have closed their doors to forestall runs that they feared would materialize. Institutions whose deposits remained stable in the spring sustained larger losses of deposits before closing their doors. If we use the rate of withdrawals from banks in Tampa on July $16^{\text {th }}$ and $17^{\text {th }}$ (as reported in the minutes of the Board of the Federal Reserve Bank of Atlanta) as a benchmark, then we can approximate how many days banks stayed open before closing. Using this metric, more than half of all banks closed on the first day that they were run. Most remaining banks suspended on the second day that they were run. A few opened on the third morning, but none survived three full days.

Of course, once runs spread more widely and a fire sale begins, spillovers to otherwise solvent institutions are likely to occur and a vicious cycle can develop which would push failures notably higher (Summers, 2008). These findings are consistent with the evidence from the Atlanta Fed's archives in that it suggests that the Fed's intervention played an important role in stopping the panic and from preventing an even more severe crisis from occurring.

\footnotetext{
${ }^{20}$ Two other examples support the 30 percent drop as a reasonable benchmark. Mississippi experienced a banking panic in November -December 1930 where the Fed did not intervene; in this episode the gross outflow of deposits was also approximately 30 percent. The WPA study of 67 medium-sized banks that
} 


\section{Conclusion}

Just as the Federal Reserve took emergency measures to respond to the financial crisis of 2008 and 2009, the Federal Reserve Bank of Atlanta was willing to undertake extraordinary measures in the summer of 1929 to prevent a meltdown of Florida's financial system. After the failure of Citizens Bank group, the Atlanta Fed responded to the panic taking place in key correspondent banks in Tampa by shuttling cash from its headquarters to the scene of banking distress, and by publicly pronouncing that it would take all means necessary to ensure the safety of depositors. Without this intervention, we estimate that bank failures would otherwise have been twice as high as what they turned out to be.

The response by the Atlanta Fed stands out for two reasons. First, it suggests that prior to 1930 the Federal Reserve had the knowledge and experience to calm anxious depositors and bankers during a panic. Federal Reserve officials demonstrated that they could effectively leverage their discount window lending capability with public announcements. This raises intriguing questions about the Federal Reserve's response to Depression-era bank panics where the Federal Reserve has been criticized as not responding forcefully enough. Scholars have put forth a number of potential reason why this might have been the case, though the matter is far from resolved. Friedman and Schwartz (1963) argued that the Fed was either unwilling or unable to provide support. Wood (2005) argues that the Federal Reserve was more focused on the New York financial markets, especially the money markets, for signs of panics. Eichengreen (1992) and Temin (1989) emphasized that the Fed was constrained in its ability to respond as long as it stayed on the gold standard. Given that considerably more control over policy was given to the regional Federal Reserve Banks at that time, and, as pointed out by Wood (2006) and Meltzer (2003), there was considerable disagreement among the Reserve Banks and between the Reserve

suspended during the Great Depression finds that average deposits declined by 37 percent prior over a period of two years prior to suspension (Federal Reserve Bulletin, March 1939, p. 178). 
Banks and the Board of Governors about the cause and appropriate response to the economic stresses during the 1930s, formulating a strong response to the more widespread Depression-era banking panics might have been difficult. This challenge may have provided a further impetus for the strengthening of the Board of Governors during the financial reform acts of the 1930s.

Recent scholarship has provided evidence that more activist lender of last resort policies during panics might have helped moderate the number of banking failures during the 1930s. Carlson (2010) argues that panics can be disruptive because the increased difficulty obtaining accurate information during such periods combined with an elevated number of banks needing assistance during these periods can reduce the number of banks able to recapitalize or merge with other institutions and thus raise the number of failures. Further, Richardson and Troost (2009) find that active lending by the Federal Reserve during the panics of the Depression helped reduce bank failures.

This brings us to the second reason why the episode is important. The Florida banking panic illustrates how an insolvency shock (in this case the potential losses stemming from the destruction of the citrus crop) can induce runs on banks and a precipitate a liquidity crisis. We also describe how correspondent banking networks can transmit shocks from the smaller institutions to the main liquidity providing banks. We demonstrate that problems at these correspondents can then spread back out to other banks and provide a channel for contagion.

The Florida banking panic nevertheless shows how central bank policy interventions can be successfully used to respond to shocks of this nature as the intervention by the Atlanta Fed appears to have contributed importantly to ending the liquidity crisis and our estimates suggest it kept some otherwise solvent banks from being closed. 


\section{References}

Allen, Franklin, and Douglas Gale. (2000). “Financial Contagion.” Journal of Political Economy 108(1), pp. 1-33.

Atkeson, Andrew. (2000). "Comment on 'Rethinking Multiple Equilibria in Macroeconomic Modeling.’” NBER Macroeconomic Annual 2000 15: 162-71.

Bernanke, Ben. (2009). "Reflections on a Year of Crisis.” Speech at Federal Reserve Bank of Kansas City's Annual Economic Symposium, Jackson Hole, Wyoming.

Brunnermeier, Markus and Lasse Pederson (2009). "Market Liquidity and Funding Liquidity.” Review of Financial Studies 22(6): 2201-2238.

Calomiris, Charles, and Joseph Mason. (1997). "Contagion and Bank Failures During the Great Depression: The June 1932 Chicago Banking Panic,” American Economic Review 87(5): 863883.

Calomiris, Charles and Joseph Mason. (2003). "Fundamentals, Panics, and Bank Distress During the Depression.” American Economic Review Vol. 93(5), pp. 1615-1647.

Carlson, Mark (2005). “Causes of Bank Suspensions in the Panic of 1893.” Explorations in Economic History 42:56-80.

Carlson, Mark. (2010). “Alternatives for Distressed Banks during the Great Depression.” Journal of Money, Credit, and Banking 42(2-3): 421-442.

Comptroller of the Currency. (various years). Annual Report. Washington, D.C.: United States Government Printing Office.

Comptroller of the Currency. (various years). Statements of Condition. Washington, DC: United States Government Printing Office.

Comptroller of the State of Florida Banking Department. (various years). Annual Report. Tallahassee: State of Florida.

Diamond, Douglas V. and Raguram Rajan. (2005). "Liquidity Shortages and Banking Crises.” Journal of Finance 60(2): 615-47.

Dovell, J. E. (1955). “History of Banking in Florida 1928-1954.” Orlando, FL: Florida Bankers Association.

Eichengreen, Barry. (1992). Golden Fetters: The Gold Standard and the Great Depression, 19191939. New York: Oxford University Press.

Federal Reserve Board of Governors. (1931). Report of the Branch, Chain, and Group Banking Committee. Washington, DC: Board of Governors. 
Federal Reserve Board of Governors. (1938). The Establishment and Operation of Branches, Agencies and Currency Funds of Federal Reserve Banks. Washington, DC: Board of Governors.

Friedman, Milton and Anna Schwartz. (1963). A Monetary History of the United States, 18671960. Princeton, NJ: Princeton University Press.

Garrett, Franklin M. (1956). History of the Federal Reserve Bank of Atlanta. Unpublished manuscript, Federal Reserve Bank of Atlanta.

Goldstein, Itay., and Ady Pauzner. 2005. "Demand-Deposit Contracts and the Probability of Bank Runs.” Journal of Finance 90(3): 1293-1327.

Hellwig, Christian, Mukherji, Arijit, and Aleh Tsyvinski. (2006). "Self-Fulfilling Currency Crises: The Role of Interest Rates.” American Economic Review 96(5): 1769-87.

Meltzer, Allan. (2003). A History of the Federal Reserve. Chicago, IL: University of Chicago Press.

Morris, Stephen and Hyun Song Shin. (2000), "Rethinking Multiple Equilibria in Macroeconomic Modeling.” NBER Macroeconomic Annual 2000 15: 139-161.

Rand McNally. (various years). Rand McNally Bankers Directory and the Bankers Registry. Chicago: Rand McNally \& Co.

Richardson, Gary and William Troost. (2009), “Monetary Intervention Mitigated Banking Panics during the Great Depression: Quasi-experimental Evidence from a Federal Reserve District Border, 1929-1933.” Journal of Political Economy 117(6): 1031-73.

Summers, Lawrence. (2000). "International Financial Crises: Causes, Preventions, and Cures.” American Economic Review 90(2): 1-16.

Temin, Peter. (1989). Lessons from the Great Depression. Cambridge, MA: MIT Press.

Upham, Cyril and Edwin Lamke. (1934). “Closed and Distressed Banks.” Washington, D.C.: The Brookings Institution.

U.S. Department of Commerce. (1910, 1920, 1930). Census of the United States. Washington, DC: Department of Commerce.

White, Eugene. (1984). “A Reinterpretation of the Banking Crisis of 1930.” Journal of Economic History 44(1): 119-138.

Wood, John. (2005). A History of Central Banking in Great Britain and the United States. New York, NY: Cambridge University Press. 
Figure 1

Orange Trees in Florida, 1929

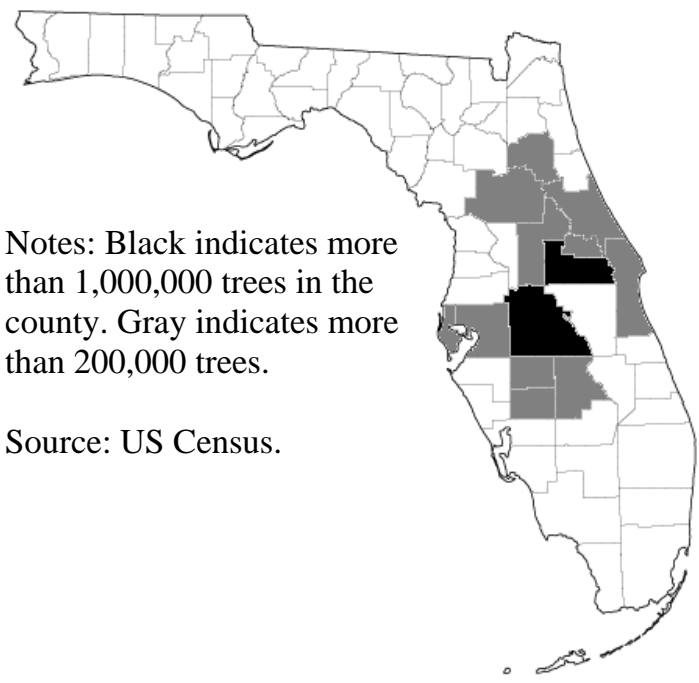

Figure 3

Original Infestation: Counties Where

Fruit Fly Detected Before 15 April

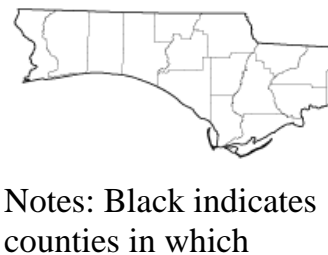
counties in which Mediterranean Fruit Fly detected on or before April 15, 1929.

Source: US Senate, 1941.
Figure 2

Fruit Revenues in Florida, 1929

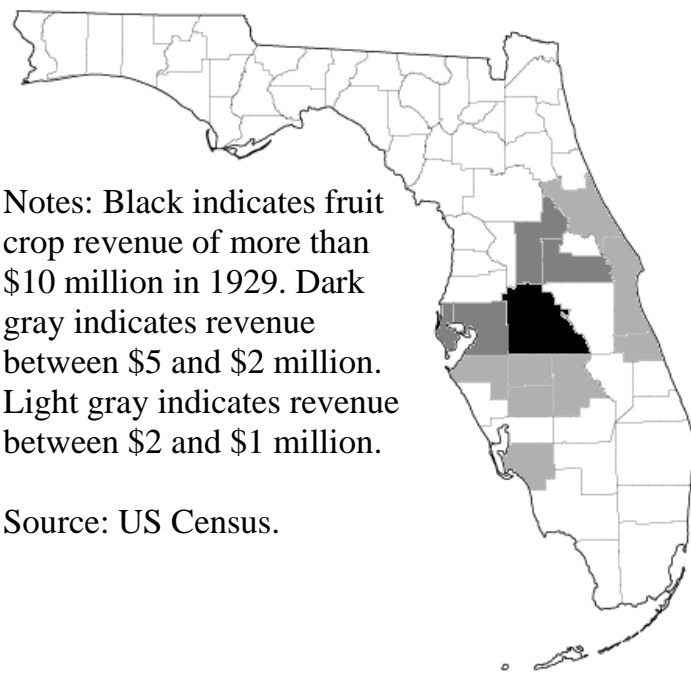

Figure 4

Quarantine: Counties Containing Zone 1 and Zone 2 Quarantines

Notes: Black indicates counties containing Zone 1 and Zone 2 quarantines. Gray indicates counties containing Zone 2 quarantines.

Source: US Senate, 1941.

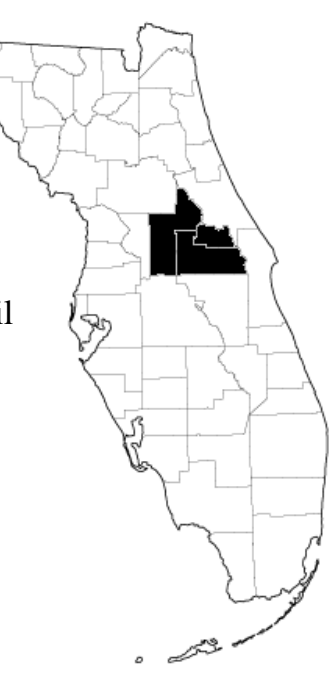


Figure 5. Bank Suspensions in Florida, Weekly, 1929

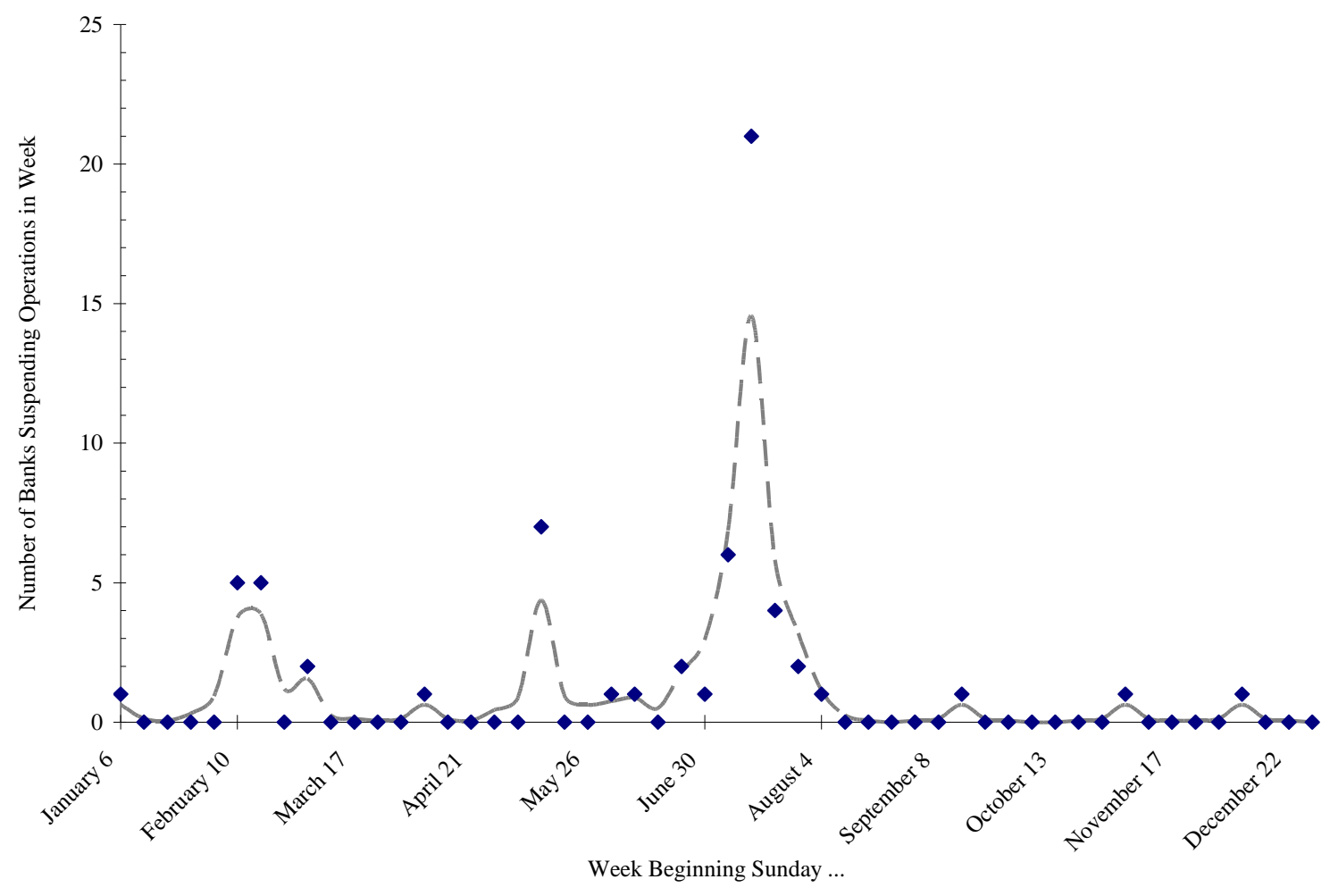

Source: See text.

Notes: Solid symbols indicate number of banks suspending each week. Dotted line indicates a weighted moving average of the weekly number of failures. The kernel averaging formula of $\mathrm{N}_{\mathrm{t}}=$ $\mathrm{n}_{\mathrm{t}-2} / 16+\mathrm{n}_{\mathrm{t}-1} / 8+(5 / 8) * \mathrm{n}_{\mathrm{t}}+\mathrm{n}_{\mathrm{t}+1} / 8+\mathrm{n}_{\mathrm{t}+2} / 16$ provides a smoothed series without obscuring surges in suspensions. Counts include banks in the Citizens Banking Group. 


\section{Figure 6}

\section{Bank Failures in Florida 1929 due to the Infestation of the Mediterranean Fruit Fly}

Bank Failures 1st Quarter

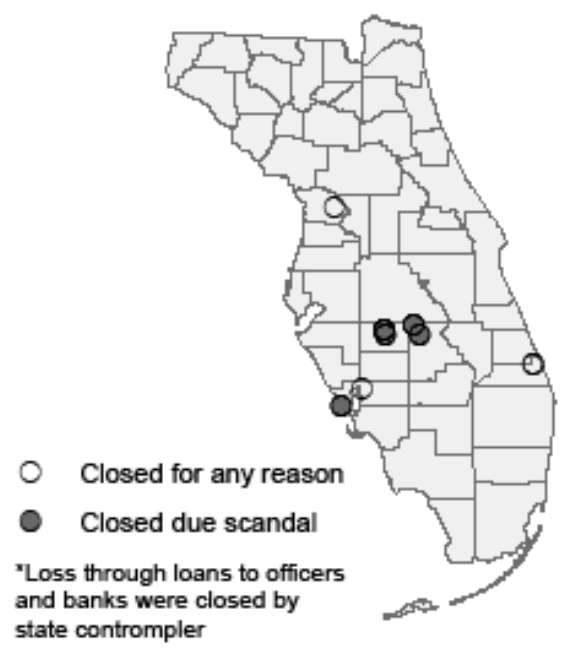

Bank Failures 3rd Quarter

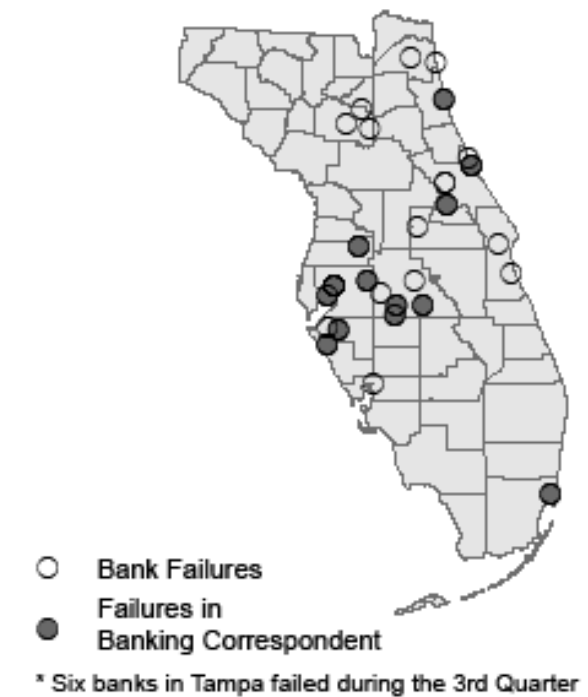

Bank Failures 2nd Quarter

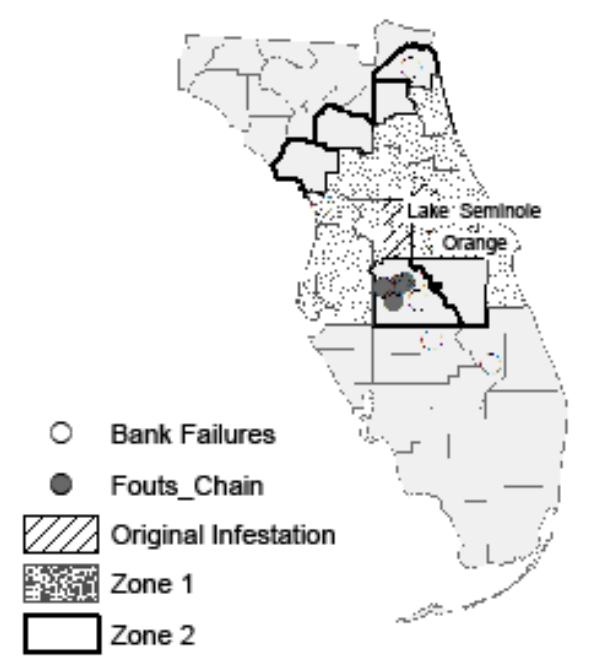

$\approx \approx$ Cross hatched area indicates counties in which Mediterranean Fruit Fly detected on or before April 15, 1929

Florida Bank Failures 1929

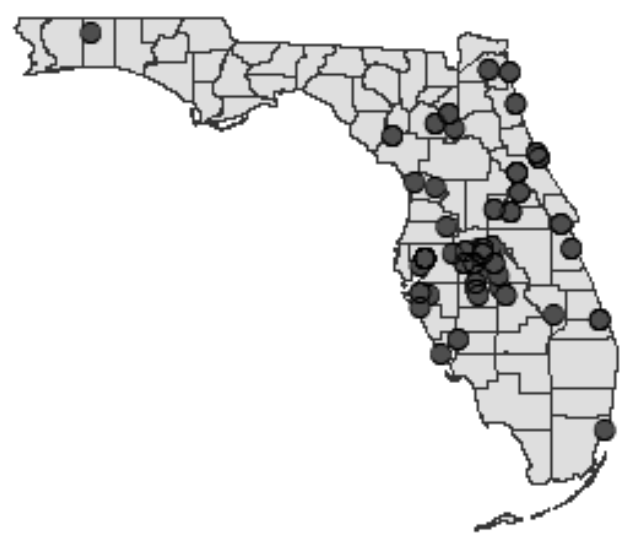


Table 1. Major Correspondent Banking Relationships in Florida, 1929

\begin{tabular}{|c|c|c|c|c|c|}
\hline $\begin{array}{c}\text { Major } \\
\text { Correspondent } \\
\text { Bank }\end{array}$ & $\begin{array}{c}\text { Location } \\
\text { of } \\
\text { Major } \\
\text { Correspondent } \\
\text { Bank }\end{array}$ & $\begin{array}{c}\text { Number } \\
\text { of } \\
\text { Respondents }\end{array}$ & $\begin{array}{l}\text { Number of } \\
\text { Respondents } \\
\text { using } \\
\text { Citizens } \\
\text { Bank }\end{array}$ & $\begin{array}{c}\text { Number of } \\
\text { Respondents } \\
\text { using another } \\
\text { large } \\
\text { Correspondent } \\
\text { Bank }\end{array}$ & $\begin{array}{c}\text { Number } \\
\text { Respondents } \\
\text { in Counties } \\
\text { subject to } \\
\text { Quarantine } \\
\text { (Zones } \\
1 \& 2 \text { ) }\end{array}$ \\
\hline $\begin{array}{l}\text { Citizens Bank } \\
\text { and Trust } \\
\text { Company }\end{array}$ & Tampa & 20 & 20 & 10 & 14 \\
\hline $\begin{array}{l}\text { Atlantic } \\
\text { National Bank }\end{array}$ & Jacksonville & 114 & 5 & 42 & 53 \\
\hline $\begin{array}{l}\text { Florida } \\
\text { National Bank }\end{array}$ & Jacksonville & 59 & 4 & 24 & 31 \\
\hline $\begin{array}{l}\text { Barnett } \\
\text { National Bank }\end{array}$ & Jacksonville & 36 & 0 & 19 & 17 \\
\hline $\begin{array}{l}\text { Exchange } \\
\text { National Bank }\end{array}$ & Tampa & 31 & 1 & 23 & 17 \\
\hline $\begin{array}{l}\text { First National } \\
\text { Bank of } \\
\text { Tampa }\end{array}$ & Tampa & 19 & 1 & 13 & 10 \\
\hline $\begin{array}{l}\text { American } \\
\text { National Bank } \\
\text { of Pensacola }\end{array}$ & Pensacola & 10 & 0 & 7 & 0 \\
\hline $\begin{array}{l}\text { First National } \\
\text { Bank of } \\
\text { Miami }\end{array}$ & Miami & 7 & 0 & 5 & 0 \\
\hline $\begin{array}{l}\text { Bank of Bay } \\
\text { Biscayne }\end{array}$ & Miami & 7 & 0 & 5 & 0 \\
\hline
\end{tabular}

Notes: A correspondent is a hub bank that provides clearing, liquidity, and other services to respondent banks. Major correspondents are defined as those with seven or more respondents. 
Table 2. Deposit Outflows by Quarantine Status

\begin{tabular}{|l|r|r|r|l|}
\hline & Median & Mean & Std. Dev & N \\
\hline Banks Outside Fruit-Fly Quarantine Zone & & & & \\
March to June 30 or Failure & -3.6 & 1.2 & 39.6 & 77 \\
June 30 to September or Failure & -0.0 & 1.3 & 25.2 & 76 \\
March to September or Failure & -3.9 & -0.9 & 26.0 & 75 \\
& & & & \\
\hline Banks in Partially Zoned Counties & -7.9 & -12.2 & 23.7 & 41 \\
March to June 30 or Failure & -0.0 & -2.3 & 16.7 & 32 \\
June 30 to September or Failure & -5.7 & -9.0 & 21.5 & 32 \\
March to September or Failure & & & & \\
& & & & \\
Banks in Completely Zoned Counties & -7.2 & -2.6 & 28.9 & 62 \\
March to June 30 or Failure & -0.0 & 1.8 & 32.1 & 60 \\
June 30 to September or Failure & -5.4 & -1.7 & 35.2 & 60 \\
March to September or Failure & & & & \\
\hline
\end{tabular}

Note: Polk's Banker's Encyclopedia did not update balance sheet data for sixty-four banks between the March and September editions. These institutions tended to be small, state chartered, country banks in the extremities of the state. All survived the fruit-fly crisis of 1929. These banks have been excluded from the calculations.

\section{Table 3. Deposit Drains on Citizens’ Bank Group and its Correspondents}

\begin{tabular}{|l|r|r|r|l|}
\hline & Median & Mean & Std. Dev & N \\
\hline Banks Without Tampa Correspondents & & & & \\
March to June 30 or Failure & -4.7 & -0.2 & 35.6 & 129 \\
June 30 to September or Failure & -0.1 & 1.6 & 28.4 & 126 \\
March to September or Failure & -4.7 & -0.4 & 30.7 & 125 \\
& & & & \\
\hline Citizens Group & -12.4 & -16.5 & 12.0 & 11 \\
March to June 30 or Failure & -15.2 & -15.5 & 5.3 & 11 \\
June 30 to September or Failure & -27.2 & -29.0 & 13.2 & 11 \\
March to September or Failure & & & & \\
& & & & \\
\hline Citizens Network (excludes group) & -19.9 & -19.1 & 25.0 & 20 \\
March to June 30 or Failure & -10.1 & -4.5 & 28.6 & 16 \\
June 30 to September or Failure & -21.3 & -18.4 & 23.8 & 16 \\
March to September or Failure & & & & \\
\hline
\end{tabular}

Note: Polk’s Banker's Encyclopedia did not update balance sheet data for sixty-four banks between the March and September editions. These institutions tended to be small, state chartered, country banks in the extremities of the state. All survived the fruit-fly crisis of 1929. These banks have been excluded from the calculations. 
Table 4. Deposit Pressure on the other National Banks in Tampa

\begin{tabular}{|l|r|r|r|l|}
\hline & Median & Mean & Std. Dev & N \\
\hline Banks Without Tampa Correspondents & & & & \\
March to June 30 or Failure & -4.7 & -0.2 & 35.6 & 129 \\
June 30 to September or Failure & -0.1 & 1.6 & 28.4 & 126 \\
March to September or Failure & -4.7 & -0.4 & 30.7 & 125 \\
& & & & \\
\hline Correspondents of First National Bank & & & & \\
March to June 30 or Failure & 0.0 & -3.0 & 9.6 & 10 \\
June 30 to September or Failure & -3.5 & -1.8 & 18.2 & 10 \\
March to September or Failure & & & & \\
\hline Correspondents of Exchange National Bank & & & & \\
March to June 30 or Failure & 0.0 & 0.8 & 13.7 & 18 \\
June 30 to September or Failure & -1.9 & -6.8 & 19.0 & 18 \\
March to September or Failure & & & & \\
\hline
\end{tabular}

Note: Polk’s Banker's Encyclopedia did not update balance sheet data for sixty-four banks between the March and September editions. These institutions tended to be small, state chartered, country banks in the extremities of the state. All survived the fruit-fly crisis of 1929. These banks have been excluded from the calculations. 
Table 5. Predicting Bank Health Using First Quarter of 1929 Characteristics

Dependent Variable: suspension prior to June 26

\begin{tabular}{|c|c|c|c|}
\hline Independent Variable & Coefficient & Std. Err. & P-value \\
\hline Log assets & .41 & .40 & .31 \\
\hline Interest earning to total assets & -.02 & .04 & .60 \\
\hline Bonds to interest earning assets & -.09 & .02 & .00 \\
\hline Net worth to assets & -.03 & .04 & .38 \\
\hline Cash to deposits & -.07 & .03 & .02 \\
\hline State Bank & -.56 & .61 & .36 \\
\hline Log town population & -.33 & .22 & .14 \\
\hline Log age of bank & -.09 & .04 & .01 \\
\hline Constant & 2.48 & 5.36 & .64 \\
\hline Observations & 264 & & \\
\hline Suspensions & 24 & & \\
\hline Log likelihood & -60.7 & & \\
\hline
\end{tabular}

Note. Equation estimated using a logit regression. Negative coefficients indicate that the variable increases the odds of survival. 


\section{Table 6. Predicting Bank Failures during the Panic Period}

Dependent Variable: suspension in a particular period

\begin{tabular}{lcc}
\hline Independent Variable & Coefficient & Std. Err. \\
& & \\
Period 1 & $-4.24^{* * *}$ & .92 \\
Period 2 & $-5.85^{* * *}$ & 1.14 \\
Period 3 & $-4.39^{* * *}$ & 2.34 \\
Period 4 & $-4.56^{* * *}$ & 4.45 \\
Has a large Jacksonville corresp. & -.83 & .63 \\
Has large non-Jacksonville corresp.*period 1 & $-1.83^{*}$ & 1.00 \\
Has large non-Jacksonville corresp.*period 2 & .59 & 1.60 \\
Has large non-Jacksonville corresp.*period 3 & -1.64 & 1.22 \\
Has large non-Jacksonville corresp.*period 4 & ---- & \\
Large non-Jacksonville corresp. fails & $2.67^{* *}$ & 1.32 \\
Run in county*period 1 & $2.15^{* * *}$ & .74 \\
Run in county*period 2 & .98 & 1.30 \\
Run in county*period 3 & $1.56^{*}$ & .93 \\
Run in county*period 4 & .59 & 1.20 \\
County quarantined & $1.64^{* *}$ & .70 \\
Survival probability*period 1 & -2.26 & 2.39 \\
Survival probability*period 2 & -2.20 & 3.39 \\
Survival probability*period 3 & -2.89 & 2.38 \\
Survival probability*period 4 & $-6.09^{*}$ & 3.37 \\
& & \\
Observations & 766 & \\
Banks & 221 \\
Suspensions & 39 & \\
Log pseudo likelihood & -91.3 &
\end{tabular}

Note. Equation estimated using a logit regression. Negative coefficients indicate that the variable increases the odds of survival. Standard errors adjusted for clustering at the bank level. ** indicates $\mathrm{p}<0.01$ and * indicates $\mathrm{p}<0.05$. 
Table 7. Estimating Expected Bank Failures for the Panic Period, July 20 to August 5, 1929

\begin{tabular}{|l|c|c|c|}
\hline Scenario & $\begin{array}{c}\text { Average failure } \\
\text { probability }\end{array}$ & $\begin{array}{c}\text { Number of } \\
\text { institutions at risk }\end{array}$ & $\begin{array}{c}\text { Actual or expected } \\
\text { bank failures }\end{array}$ \\
\hline Actual failures & & & 8 \\
Baseline regression & .039 & 205 & 8 \\
$\begin{array}{l}\text { Failure of Exchange National \& } \\
\text { First National of Tampa }\end{array}$ & .066 & 205 & 14 \\
$\begin{array}{l}\text { All non-Jacksonville correspondents } \\
\text { fail }\end{array}$ & .076 & 205 & 61 \\
$\begin{array}{l}\text { All correspondents fail (including } \\
\text { Jacksonville correspondents) }\end{array}$ & .300 & 205 & \\
\hline
\end{tabular}

Note. The last three rows provide counterfactual estimates for failures. See the text for details.

\section{Table 8. "Fire Sale” Stress Tests}

\begin{tabular}{|l|c|c|c|c|}
\hline $\begin{array}{l}\text { Hypothetical } \\
\text { decline in deposits } \\
\text { due to bank runs }\end{array}$ & \multicolumn{2}{|c|}{$\begin{array}{c}\text { Number of Suspensions/Fire Sales: } \\
\text { All Florida Banks }\end{array}$} & \multicolumn{2}{c|}{$\begin{array}{c}\text { Number of Suspensions/Fire Sales: } \\
\text { Banks in Quarantine Zones 1 \& 2 }\end{array}$} \\
\hline $5 \%$ & Exhaust Cash & $\begin{array}{c}\text { Exhaust Cash and } \\
\text { Securities }\end{array}$ & Exhaust Cash & $\begin{array}{c}\text { Exhaust Cash and } \\
\text { Securities }\end{array}$ \\
$10 \%$ & 0 & 0 & 0 & 0 \\
$15 \%$ & 3 & 0 & 2 & 0 \\
$20 \%$ & 51 & 0 & 11 & 0 \\
$25 \%$ & 98 & 1 & 25 & 1 \\
$30 \%$ & 139 & 16 & 52 & 7 \\
$35 \%$ & 162 & 25 & 69 & 9 \\
\hline
\end{tabular}

Note: The table shows how many banks that would have exhausted various liquid assets given the decline in deposits shown in column 1. 13.2 percent is the deposit loss before suspension (from June 30 until midJuly) experienced by banks that failed during the July panic. 22 percent is the deposit loss before suspension (from January until suspension) for all banks that failed during the year of 1929. 